\title{
Effect of Ramdan month on the selected Physiological and Physical fitness components of college students
}

\author{
MD. Mainur Rahman ${ }^{1}$ H. Surendra Sharma ${ }^{2}$ Muneer Ahmad Ganie ${ }^{3}$ \\ ${ }^{1,2}$ (Research scholar, Department of Physical education, CMJ University, Shillong, India) \\ ${ }^{3}$ (Research scholar, Dr. C.V Raman University, Maharastra, India)
}

\begin{abstract}
The main purpose of the study was to find out the effect of one month fast during Ramdan month on the selected Physiological and Physical fitness components of college students. It was hypothesized that there would be significant effect of one month fasting on selected Physiological and Physical fitness components. 30 male students studied in B.P.E, B.P.Ed and M.P.Ed Courses were selected as subjects. Agility shows the significant difference between the Means of Pre-and Post-test of Ramdan. It also indicates that no other selected variables show significant difference between the Pre-and Post-test Mean, as the obtained t-value of Systolic Blood Pressure, Diastolic Blood Pressure, Pulse Rate, Lean Body Weight, Fat Weight, Total Body Weight, Speed and Explosive Leg Strength are less than the tabulated $t$-value.
\end{abstract}

Keywords: Ramdan, physiological, physical fitness components, systolic diastolic blood pressure, pulse rate, lean body weight, fat weight.

\section{Introduction:}

During the holy month of Ramadan, Muslims refrain from eating or drinking starting from dawn till dusk. To prepare for the fasting, Muslims wake up before dawn and the fajr prayer to eat a meal (Sahoor). Muslims break their fast at Maghrib (at sunset) prayer time with a meal called Iftar. Muslims are expected to put more effort into following the teachings of Islam and to avoid obscene and irreligious sights and sounds. The fast is intended to be an exacting act of deep personal worship in which Muslims seek a raised awareness of closeness to God. The act of fasting is said to redirect the heart away from worldly activities, its purpose being to cleanse the inner soul and free it from harm. It also teaches Muslims to practice self-discipline, selfcontrol, sacrifice, and empathy for those who are less fortunate; thus encouraging actions of generosity and charity. Fasting in the month of Ramadan is compulsory on every Muslim adult. The main purpose of the study was to find out the effect of one month fast during Ramdan month on the selected Physiological and Physical fitness components of college students. It was hypothesized that there would be significant effect of one month fasting on selected Physiological and Physical fitness components.

Aziz, Wahid, Png and Jesuvadi (2010) studied on Effects of Ramadan fasting on 60 min of endurance running performance in moderately trained men. This study examines the effects of Ramadan fasting on endurance performance. Using a crossover design, 10 moderately trained, active Muslim men performed 60 min runs on a treadmill in the fasted (Ramadan, RAM) and non-fasted (Control, CON) state on two separate counterbalanced occasions. After familiarization, four subjects performed their CON trial 1 week before Ramadan, while the other six subjects performed their CON trial 1 week after the Ramadan month. The subjects' last meals were standardised before their exercise trials. The $60 \mathrm{~min}$ continuous endurance running criteria test consisted of 30 min preloading run at $65 \%$ maximum oxygen consumption $(\operatorname{Vo}(2 \mathrm{max})$ ) intensity speed, followed by another $30 \mathrm{~min}$ time trial (TT) where subjects manually adjusted their speeds so as to cover the greatest possible distance. Subjects ran significantly further during the $30 \mathrm{~min}$ TT run in the CON compared to RAM condition ( $5649+/-715$ vs $5448+/-847 \mathrm{~m}, \mathrm{p}=0.023)$. Blood glucose concentration was significantly lower $(4.5+/-0.3 \mathrm{vs} 4.9+/-0.4 \mathrm{mmol} / \mathrm{l}, \mathrm{p}=0.003)$ and urine specific gravity was significantly higher $(1.018+/-0.006 \mathrm{vs}$ $1.006+/-0.004, \mathrm{p}=0.001)$ at the start of exercise in the RAM condition than in CON. Physiological responses during the $30 \mathrm{~min}$ TT run (mean heart rate, blood lactate and ratings of perceived exertion) were, however, not significantly different between the two conditions (all $\mathrm{p}>0.05$ ). There were also no significant differences in the subjects' daytime sleepiness or mood profile between the RAM and CON conditions (all p>0.05). Ramadan fasting has a small yet significant negative impact on endurance running performance, although the impact varies across individuals. Maughan, Fallah, Coyle (2010) studied on The effects of fasting on metabolism and performance. An overnight fast of $8-10 \mathrm{~h}$ is normal for most people. Fasting is characterised by a coordinated set of metabolic changes designed to spare carbohydrate and increase reliance on fat as a substrate for energy supply. As well as sparing the limited endogenous carbohydrate, and increased rate of gluconeogenesis from 
amino acids, glycerol and ketone bodies help maintain the supply of carbohydrate. Many individuals undergo periodic fasts for health, religious or cultural reasons. Ramadan fasting, involving 1 month of abstention from food and fluid intake during daylight hours, is practised by a large part of the world population. This period involves a shift in the pattern of intake from daytime to the hours of darkness. There seems to be little effect on overall daily dietary intake and only small metabolic effects, but there may be implications for both physical and cognitive function.

\section{Methodology:}

For the purpose of the study 30 male students studied in B.P.E, B.P.Ed and M.P.Ed Courses were selected as subjects. The age of subjects was ranging from 18 to 28 years. Pulse rate was measured manually for 1 minute and the score was recorded in number. Systolic and Diastolic blood pressure were measured by using Sphygmomanometer and Stethoscope and the score was recorded in mmHg. Total body weight was measured with the help of weighing machine and the score was recorded in kilogram. Fat weight and lean body weight were calculated by employing four sites skin fold thickness namely Biceps, Triceps, Sub-scapular, Supra-iliac then following Rehman and Durnin's ready reconer fat weight was determined. Speed was measured by applying 50 meter dash and the score was recorded in seconds. By administrating $4 \times 10$ yards shuttle run agility was measured and the score was recorded in seconds. Explosive strength was measured by using standing broad jump and the score was recorded in centimeters. The data were collected on the all selected subjects by applying the above mentioned test items just before and immediately after the Ramdan month.

\section{Result:}

To find out the deference in selected Physiological and Physical fitness components of the selected subjects between the pre and post test mean dependent $t$-test was employed and to test the hypothesis level of significance was set at 0.05 . Comparison of means is given in the following below table.

Table - I

Summary of Mean, Standard Deviation and t-ratio of Pre test and Post test for the selected variables in Ramdan.

\begin{tabular}{|c|c|c|c|c|c|c|}
\hline Variable & Test & Mean & $\begin{array}{l}\text { Standard } \\
\text { Deviation }\end{array}$ & $\begin{array}{l}\text { Mean } \\
\text { Difference }\end{array}$ & $\begin{array}{l}\text { Standard } \\
\text { Error }\end{array}$ & t-ratio \\
\hline \multirow{2}{*}{$\begin{array}{l}\text { Systolic } \\
\text { Blood } \\
\text { Pressure }\end{array}$} & Pre test & 115.67 & 6.97 & \multirow{2}{*}{3.10} & \multirow{2}{*}{2.07} & \multirow{2}{*}{1.497} \\
\hline & Post test & 112.57 & 8.93 & & & \\
\hline \multirow{2}{*}{$\begin{array}{l}\text { Diastolic } \\
\text { Blood } \\
\text { Pressure }\end{array}$} & Pre test & 76.2 & 4.88 & \multirow{2}{*}{1.00} & \multirow{2}{*}{1.45} & \multirow{2}{*}{0.69} \\
\hline & Post test & 75.2 & 6.25 & & & \\
\hline \multirow[t]{2}{*}{ Pulse Rate } & Pre test & 72.07 & 3.52 & \multirow{2}{*}{0.34} & \multirow{2}{*}{0.98} & \multirow{2}{*}{0.35} \\
\hline & Post test & 71.73 & 4.11 & & & \\
\hline \multirow{2}{*}{$\begin{array}{l}\text { Lean Body } \\
\text { Weight }\end{array}$} & Pre test & 55.76 & 4.75 & \multirow{2}{*}{0.92} & \multirow{2}{*}{1.22} & \multirow{2}{*}{0.75} \\
\hline & Post test & 54.84 & 4.72 & & & \\
\hline \multirow[t]{2}{*}{ Fat Weight } & Pre test & 8.107 & 4.54 & \multirow{2}{*}{1.11} & \multirow{2}{*}{1.133} & \multirow{2}{*}{0.98} \\
\hline & Post test & 6097 & 423 & & & \\
\hline \multirow{2}{*}{$\begin{array}{l}\text { Total Body } \\
\text { Weight }\end{array}$} & Pre test & 63.47 & 8.56 & \multirow{2}{*}{1.64} & \multirow{2}{*}{2.12} & \multirow{2}{*}{0.77} \\
\hline & Post test & 61.83 & 7.86 & & & \\
\hline \multirow{2}{*}{$\begin{array}{l}\text { Speed } \\
\text { (50y. } \\
\text { Dash) }\end{array}$} & Pre test & 7.49 & 0.36 & \multirow{2}{*}{0.18} & \multirow{2}{*}{0.099} & \multirow{2}{*}{1.82} \\
\hline & Post test & 7.31 & 0.41 & & & \\
\hline \multirow{2}{*}{$\begin{array}{l}\text { Agility } \\
(4 \times 10 y \\
\text { Shuttle })\end{array}$} & Pre test & 11.07 & 0.39 & \multirow[b]{2}{*}{0.21} & \multirow[b]{2}{*}{0.093} & \multirow[b]{2}{*}{$2.25^{*}$} \\
\hline & Post test & 10.86 & 0.33 & & & \\
\hline Power & Pre test & 2.14 & 0.12 & & & \\
\hline
\end{tabular}




\begin{tabular}{|l|l|l|l|l|l|l|}
\hline $\begin{array}{l}\text { (Standing } \\
\text { Broad } \\
\text { Jump) }\end{array}$ & Post test & 2.11 & 0.10 & 0.03 & 0.028 & 1.07 \\
\hline
\end{tabular}

* Significant at .05 level.

Tabulated t.05 (29) $=2.045$

\section{Discussion:}

It is evident from the above table that only Agility shows the significant difference between the Means of Pre-and Post-test of Ramdan because the calculated t-value of 2.25 is greater than the tabulated t-value of 2.045. The table also indicates that no other selected variables show significant difference between the Pre-and Post-test Mean, as the obtained $t$-value of Systolic Blood Pressure ( $\mathrm{t}=1.497)$, Diastolic Blood Pressure $(\mathrm{t}=0.69)$, Pulse Rate ( $\mathrm{t}=0.35)$, Lean Body Weight $(\mathrm{t}=0.75)$, Fat Weight $(\mathrm{t}=0.98)$, Total Body Weight $(\mathrm{t}=0.77)$, Speed $(\mathrm{t}=1.82)$ and Explosive Leg Strength $(\mathrm{t}=1.07)$ are less than the tabulated $\mathrm{t}$-value of 2.045.

The findings of Statistical analysis revealed that the significant improvement occurred in Agility after 1 month of fasting in Ramdan. The significant improvement in Agility may be due to the reason that the subjects chosen for the study were students of Physical Education College, all the subjects were made compulsory to attend their regular practical classes, by doing so they might have improved their agility. The findings of the study also revealed that there were no significant differences between the Pre and Post test means for the selected variables. The insignificant differences might have occurred due to the fact that most of the selected subjects were belonged to mediocre family hence they could not effort to have nutritive and balanced diet after the fast. Therefore energy system might be failure to supply the desirable energy to the active muscles. But all the variables have shown improvement due to 1 month fast during Ramdan.

\section{Conclusion:}

Recognizing the limitations and on the basis of statistical results the following conclusions may be drawn:-

i) The findings of the study revealed that systolic Blood Pressure, Diastolic Blood Pressure, Pulse Rate, Lean Body Weight, Fat Weight, Total Body Weight decreased upto certain extent but not significantly.

ii) Agility significantly improved.

iii) Speed also improved but not significantly.

iv) Power decreased due to day time fasting.

v) Lastly it can be concluded that one month fasting in Ramdan is not at all harmful to the health as well as physical fitness rather it is beneficial to the health, but subject to condition during Iftar (breaking fast) and Sahuur (light meal taken before the break of dawn) nutritive food and sufficient water must be taken-up by the candidate.

\section{Reference}

[1] Katz Y, Zangen D, Leibowitz G, Szalalt A., "Diabetic Patients in the Yom Kippur Fast--Who Can Fast and How To Treat The Fasting Patients", $\mathrm{z}$

[2] Aziz AR , Wahid MF , Png W , Jesuvadian CV. "Effects of Ramadan Fasting on 60 Min of Endurance Running Performance in Moderately Trained Men.” Br J Sports Med. , 2010 Jun.

[3] Azizi F "Islamic Fasting and Health." Ann Nutr Metab. , 2010.

[4] BaHammam A, Alrajeh M, Albabtain M, Bahammam S, Sharif M., "Circadian Pattern of Sleep, Energy Expenditure, and Body Temperature of Young Healthy Men During the Intermittent Fasting Of Ramadan.", Appetite. 2010 Apr., pub 2010 Jan 25.

[5] Benbarka MM, Khalil AB, Beshyah SA, Marjei S, Awad SA., "Insulin Pump Therapy in Moslem Patients With Type 1 Diabetes During Ramadan Fasting: An Observational Report.", Diabetes Technology \& Therapeutics. 2010 Apr.

[6] Burke L "Fasting and Recovery From Exercise." Br J Sports Med. , 2010 Jun

[7] Chaouachi A, Coutts AJ, Chamari K, Wong del P, Chaouachi M, Chtara M, Roky R, Amri M., "Effect of Ramadan Intermittent Fasting on Aerobic and Anaerobic Performance And Perception Of Fatigue In Male Elite Judo Athletes.", Journal of Strength Conditioning Research, 2009 Dec.

[8] Chaouachi A, Coutts AJ, Wong del P, Roky R, Mbazaa A, Amri M, Chamari K.,"Haematological, Inflammatory, and Immunological Responses in Elite Judo Athletes Maintaining High Training Loads During Ramadan.", Applied Physiology, Nutrition Metabolism, 2009 Oct.

[9] Chaouachi A, Leiper JB, Souissi N, Coutts AJ, Chamari K., "Effects of Ramadan Intermittent Fasting on Sports Performance and Training", International Journal Sports Of Physiology And Performance, 2009 Dec.

[10] Guerrero Morilla R, Ramírez Rodrigo J, Sánchez Caravaca A, Villaverde Gutiérrez C, Ruiz Villaverde G, Pérez Moreno BA., "Dietary Modifications in Young Muslims Engaged in Ramadan Fasting", Nutricion Hospitalaria. 2009 Nov-Dec.

[11] Hui E, Bravis V, Salih S, Hassanein M, Devendra D., Jeffrey Kelson, "Comparison of Humalog Mix 50 With Human Insulin Mix 30 in Type 2 Diabetes Patients During Ramadan.", International Journal Clinical Practice, 2010 Jul, Epub 2010 Mar 